\title{
Medicinal plants, traditional medicine, markets and management in far-west Nepal
}

Ripu M Kunwar ${ }^{1,3^{*}}$, Laxmi Mahat ${ }^{2}$, Ram P Acharya ${ }^{3}$ and Rainer W Bussmann ${ }^{4}$

\begin{abstract}
Background: Modern therapeutic medicine is historically based on indigenous therapies and ethnopharmacological uses, which have become recognized tools in the search for new sources of pharmaceuticals. Globalization of herbal medicine along with uncontrolled exploitative practices and lack of concerted conservation efforts, have pushed many of Nepal's medicinal plants to the verge of extinction. Sustainable utilization and management of medicinal plants, based on traditional knowledge, is therefore necessary.

Methods: After establishing verbal informed consent with participating communities, five field surveys, roughly 20 days in duration, were carried out. In all, 176 schedules were surveyed, and 52 participants were consulted through focus group discussions and informal meetings. Altogether, 24 key informants were surveyed to verify and validate the data. A total of 252 individuals, representing non-timber forest product (NTFP) collectors, cultivators, traders, traditional healers (Baidhya), community members, etc. participated in study. Medicinal plants were free-listed and their vernacular names and folk uses were collected, recorded, and applied to assess agreement among respondents about traditional medicines, markets and management.
\end{abstract}

Results: Within the study area, medicinal herbs were the main ingredients of traditional therapies, and they were considered a main lifeline and frequently were the first choice. About 55\% plants were ethnomedicinal, and about 37\% of ethnomedicinal plants possessed the highest informant consensus value (0.86-1.00). Use of Cordyceps sinensis as an aphrodisiac, Berberis asiatica for eye problems, Bergenia ciliata for disintegration of calculi, Sapindus mukorossi for dandruff, and Zanthoxylum armatum for toothache were the most frequently mentioned. These species possess potential for pharmacology.

Conclusion: Medicinal plants are inseparable from local livelihoods because they have long been collected, consumed, and managed through local customs and knowledge. Management of traditional therapies is urged, because the therapies are empirically and knowledge based, often culturally inherited and important to pharmacology and local livelihoods. However, traditional therapies are currently being eroded due to changing lifestyles, perceptions, social transformations, and acculturation.

Keywords: Medicinal plants, Indigenous use, Sustainable management, Baidhya, Baitadi district, Nepal

\section{Introduction}

Nepal is ranked as $9^{\text {th }}$ among the Asian countries for its floral wealth with an estimated 9,000 species of flowering plants [1]. So far, 6,653 species of flowering plants have been reported [2]. Among these, about 50\% fall under the rubrics "useful" [3] and "ethnobotanical" [4], and about $25 \%-50 \%$ are ethnomedicinals $[5,6]$. Catalogues have recorded 1,792 [7] to 2,331 [8] useful medicinal and

\footnotetext{
* Correspondence: ripukunwar@gmail.com

${ }^{1}$ Center for Biological Conservation, Kathmandu, Nepal

${ }^{3}$ Practical Solution Consultancy, Kathmandu, Nepal

Full list of author information is available at the end of the article
}

aromatic plants in Nepal, reporting their importance in alleviating human suffering because they have long been used for subsistence, home remedies, and traditional therapies [5-8]. These plants are also important for local livelihoods [9] and income generation [10], and they do fetch higher market prices [11].

National and regional demands for herbal medicine are accelerating [12,13], and globalization of herbal medicine, along with uncontrolled exploitative practices and lack of concerted conservation efforts, now threaten the country's medicinal plants $[14,15]$. Numerous drugs have been

\section{() Biomed Central}

(c) 2013 Kunwar et al.; licensee BioMed Central Ltd. This is an Open Access article distributed under the terms of the Creative Commons Attribution License (http://creativecommons.org/licenses/by/2.0), which permits unrestricted use, distribution, and reproduction in any medium, provided the original work is properly cited. 
introduced to international markets [16] through validation of traditional medicines [17], indigenous therapies $[18,19]$, and ethnopharmacological practices [20]. Sustainable utilization and management of medicinal plants based on traditional knowledge is therefore necessary. It is imperative that the medicinal plants, their traditional uses, and management practices be catalogued as part of a larger conservation effort toward "rescuing a global heritage" [21]. This effort should acknowledge empirical data and ethnoecological knowledge [22,23]. Far-west Nepal is the least studied area in Nepal [20]. The present study was thus an attempt to catalogue the important medicinal plants of Far-west Nepal along with their traditional uses and management interventions.

\section{Methodology \\ Study area}

Three districts along the western border of Nepal-Baitadi, Darchula, and Dadeldhura-were selected for the present study. The districts extend between $29^{\circ} 01^{\prime}-30^{\circ} 15^{\prime} \mathrm{N}$ latitude and $80^{\circ} 15^{\prime}-81^{\circ} 09^{\prime} \mathrm{E}$ longitude; their elevation ranges between $257 \mathrm{~m}$ and $7132 \mathrm{~m}$ above sea level. In Dadeldhura, the following villages were visited: Jogbudha, Rupal, Sirsha and Sadani. In Baitadi, the villages of Siddeswor, Siddnath, Patan, and Pancheswor were visited. In Darchula, the villages of Maikholi, Khar, Khalanga, Rapla, Dumling, and Gokuleswor were visited. Community forests and their user groups were consulted in the villages of Sigas, Rameswor, Madhu, Bhumi Raj and Trishuli (Baitadi district); Tham and Dumling (Darchula district); and Shivsundari, Trishuli Mahila, Parshuram, and Siddnath (Dadeldhura district). National forests were assessed at Jogbudha and Deurali (Dadeldhura district); Pancheswor and Melauli (Baitadi district); and Gokuleswor and Rapla (Darchula district). Local markets and traders were consulted in Amargadhi and Bagarkot (Dadeldhura district); Khalanga and Dumling (Darchula district); and Khodpe, Patan, and Melauli (Baitadi district). Due to variations in altitude, topography, and bioclimate in Far-west Nepal, the diversity of medicinal plants and knowledge of their utilization varied widely.

There are a number of ethnic groups in this region, dominated by the Kshetri (more than 57\%), Brahmin (about 20\%), Kami (6\%), Sarki (3\%), Mahar (2\%), and a few others within the study area. The first two groups are relatively privileged [24], the Kami and Sarki are categorized as Dalits, and the Mahar and others are categorized as Janajati, based on the socio-cultural and class system of Nepal. The Dalits and Janajati groups are receiving special easy access opportunities provided by the government (Figure 1).

\section{Field surveys and data collection}

After establishing verbal informed consent with the participating communities, five field surveys, roughly 20 days in length, were carried out in different seasons: Spring surveys were conducted in May 2006 and March-April 2008; summer surveys were conducted in August 2009; and winter surveys were conducted in December 2006 and February 2007. Field visits were not carried out in Autumn, because it is festival season in Nepal. The primary methods of data collection consisted of group discussions, informal meetings, schedule surveys, and field observations. In all, 176 schedules were surveyed and 52 participants were consulted in focus group discussions and informal meetings. Informal meetings were held in villages during the evening, while team members were staying with local communities. Altogether, 24 key informants were surveyed to verify and validate data and information [25]. A total of 252 individuals, representing NTFP collectors, cultivators, traders, traditional healers (Baidhya), community members, etc. participated in the study. In particular, elderly people, forest guards, and women representing different ethnic groups, castes, and occupations were encouraged to participate. Among the participants, 60\% were Kshetri, 20\% Brahmin, 12\% Janajati (Chaudhary, Mahar, etc.) and $8 \%$ Dalits (Chuhar, Bijale, Lawad, Pariyar etc.). Twenty one percent of participants were women. There were altogether $88 \%$ respondents from Kshetri, Brahmin, and Dalits, and the similar account of ethnic groups was also found in three study districts [26].

All species encountered during participatory field observations were free-listed, and vouchers of medicinal plant species were collected during the day and displayed in the evening for discussions. Most of the species were identified in the field using references $[27,28]$. Common species that were frequently seen, spot-identified by study team members and local assistants, and well known by their dialect names were used only for discussion; no voucher specimens were collected for further identification. The remaining unidentified species were vouchered and stored in the National Herbarium and Plant Laboratories (KATH), Godawari, Lalitpur, Nepal. The collection of voucher specimens, along with additional information, was facilitated by local assistants. Data and information were sought on the interest of collectors/cultivators, their household economy, and their patterns of use and management of medicinal plants, etc. A wealth index was established, and active involvement of people in medicinal plant cultivation, collection and trade, as well as the net cash income of consecutive two years (2006 and 2007), were analyzed following the literature [29-32]. Vernacular names and folk uses of voucher specimens were collected and used to assess consensus among respondents [33]. Matching information from at least three respondents (mentions) was counted as a common response for analysis. The species were assessed for informant consensus value (ICV), and species with more than 0.85 ICV were considered for further analysis. 


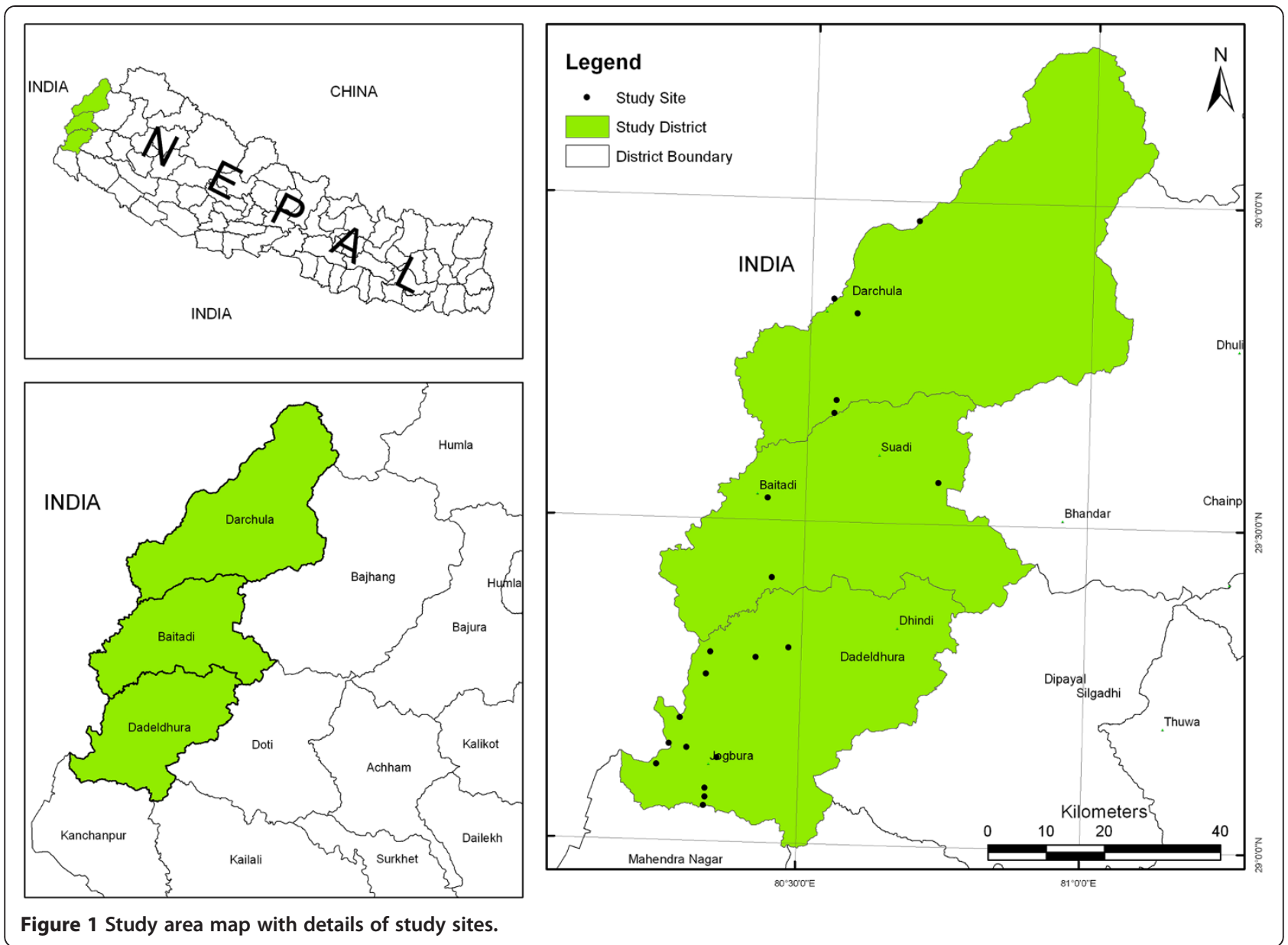

\section{Results and discussion}

This study recorded the use of 238 plant species, which were distributed among 209 genera and 92 families. Of these, 132 species (55\%) had an ethnomedicinal use. The families Asteraceae, Fabaceae, and Euphorbiaceae, and the genera Euphorbia, Ficus, and Swertia were significant sources of ingredients for folk remedies. Asteraceae and Fabaceae each contributed seven species, followed by six species from Euphorbiaceae. There were three species used as ethnomedicinals from Ficus, and two species used from Euphorbia, Rhododendron, and Swertia. The ethnomedicinal species were assessed for informant consensus value (ICV). A total of 49 plant species were found to have more than three responses (mentions) and an ICV greater than 0.85 (Table 1), indicating that they are worthy of pharmacological study.

\section{Collection of medicinal plants}

Community forests were the main sources of collection of medicinal plant products. We recorded that $49.5 \%$ collections were gathered from community forests and $18.5 \%$ from government-managed forests. The latter have been exploited as open-access free commodities, therefore their contribution to furnishing provisional products to local communities has been gradually declining. We found that only about $33 \%$ of the collections were used for subsistence (primarily as ingredient for folk remedies and food). The rest (about 67\%) was sold, thanks to increasing market prices of the wild crafted products. Collection for the market was the predominant reason behind collection in Nepal [34] and India [35]. Marketing of medicinal plant products is important to address the need for household commodities; the study area is rural and distant from road transport.

Since forests of the Himalaya are the richest habitat for medicinal plants [36] and a common property resource in Nepal [37], Dalits and Janajati groups within the study area were frequent collectors, and they gathered a disproportionate amount of forest products-particularly medicinal plants to address their subsistence and accessory needs. The overall increasing trend in collection and consumption was $16 \%$. The increase in the number of collectors per annum was about $10 \%$ for the Brahmin and Kshetri, 35\% for the Janajati, and 40\% for the Dalits. The trend was consistent with their dependency, as the Dalits are more dependent on forests [38]. Such increases were 
Table 1 Diseases/disorders, plant parts in use and mode of preparations

\begin{tabular}{|c|c|c|c|c|}
\hline \multirow{2}{*}{$\begin{array}{l}\text { Category and diseases/disorders } \\
\text { NVS - Memory longevity, migraine, epilepsy, laxative, aphrodisiac, tonic, stimulant }\end{array}$} & \multirow{2}{*}{$\begin{array}{l}\text { Total number of species } \\
\text { used }\end{array}$} & \multicolumn{3}{|c|}{ Specific disorder and species and its highest mentions and IC value } \\
\hline & & $\begin{array}{l}\text { Aphrodisiac - Cs (50) } \\
\text { ICV = } 1\end{array}$ & $\begin{array}{l}\text { Epilepsy - Ng (31) } \\
\text { ICV }=0.97\end{array}$ & Laxative - Pe (28) ICV = 0.97 \\
\hline OTH - Pesticidal, repellant, paralysis, toothache & 14 & $\begin{array}{l}\text { Pesticidal - Ac (42) } \\
\text { ICV }=0.96\end{array}$ & $\begin{array}{l}\text { Toothache }-Z a(45) \\
\mathrm{ICV}=0.95\end{array}$ & Paralysis - Ca (24) ICV = 0.96 \\
\hline $\begin{array}{l}\text { DIG - Anthelmintic, nausea, vomiting, diarrhea, gallstone, indigestion, dysentery, } \\
\text { gastric trouble }\end{array}$ & 44 & $\begin{array}{l}\text { Gall stone }-B C(43) \\
\mathrm{ICV}=0.95\end{array}$ & $\begin{array}{l}\text { Anthelmintic - VJ (32) } \\
\mathrm{ICV}=0.95\end{array}$ & $\begin{array}{l}\text { Nausea/vomiting - Ct (34) } \\
\mathrm{ICV}=0.95\end{array}$ \\
\hline OPTH - Eye disease & 4 & $\begin{array}{l}\text { Eye complaints - Ba (34) } \\
\text { ICV }=1\end{array}$ & $\begin{array}{l}\text { Eye complaints }-P n(31) \\
\text { ICV }=0.95\end{array}$ & $\begin{array}{l}\text { Eye complaints }-A p(31) \\
\text { ICV }=0.95\end{array}$ \\
\hline DER - Scabies, skin diseases, allergy, moles, hair problems & 13 & $\begin{array}{l}\text { Hair problems - Sam }(34) \\
\mathrm{ICV}=0.93\end{array}$ & $\begin{array}{l}\text { Scabies }- \text { Cop (25) } \\
\mathrm{ICV}=0.93\end{array}$ & $\begin{array}{l}\text { Skin promlem }-P z(25) \\
\mathrm{ICV}=0.93\end{array}$ \\
\hline MSK - Antispasmodic, sprain, fracture, arthritis, rheumatism & 10 & $\begin{array}{l}\text { Arthritis }-J C(33) \\
\mathrm{ICV}=0.96\end{array}$ & $\begin{array}{l}\text { Sprain }-B V(32) \\
\mathrm{ICV}=0.96\end{array}$ & $\begin{array}{l}\text { Fractures }-U d(32) I C V= \\
0.96\end{array}$ \\
\hline INJ - Cuts, wounds, sore, inflammation & 16 & $\begin{array}{l}\text { Cuts/wounds - Dh }(31) \\
\mathrm{ICV}=0.86\end{array}$ & $\begin{array}{l}\text { Wounds - Cas (31) } \\
\mathrm{ICV}=0.86\end{array}$ & Cuts - Eph (31) ICV = 0.86 \\
\hline GUS - Urinary complaints, gonorrhea, syphilis, diuretics & 11 & $\begin{array}{l}\text { Diuretics }- \text { Pe (31) } \\
\mathrm{ICV}=0.92\end{array}$ & $\begin{array}{l}\text { Diuretics - Ms (31) } \\
\mathrm{ICV}=0.92\end{array}$ & $\begin{array}{l}\text { Urinary complaints }- \text { Ach (26) } \\
\mathrm{ICV}=0.92\end{array}$ \\
\hline RES - Asthma, pneumonia, bronchitis, jaundice, cough/cold & 18 & $\begin{array}{l}\text { Jaundice }-\operatorname{Cr}(27) \\
\mathrm{ICV}=0.91\end{array}$ & $\begin{array}{l}\text { Pneumonia }- \text { Mh (24) } \\
\mathrm{ICV}=0.91\end{array}$ & Asthma - Ms (16) ICV = 0.91 \\
\hline INF - Burn, scald, boil, earache, fever & 16 & Fever - SC (26) ICV = 0.90 & $\begin{array}{l}\text { Burns }- \text { Cn (19) } \\
\mathrm{ICV}=0.90\end{array}$ & Boils - $\operatorname{Pr}(19)$ ICV $=0.90$ \\
\hline PRG - Lactation, easy delivery & 3 & $\begin{array}{l}\text { Easy Delivery - Ari (23) } \\
\mathrm{ICV}=0.97\end{array}$ & $\begin{array}{l}\text { Lactation }-\operatorname{Ar}(21) \\
\mathrm{ICV}=0.97\end{array}$ & \\
\hline $\begin{array}{l}\text { CVC - Bleeding, blood disorders, liver disorders, spleen disorders, jaundice, } \\
\text { hemorrhage }\end{array}$ & 15 & $\begin{array}{l}\text { Blood disorders - Mk (22) } \\
\mathrm{ICV}=0.94\end{array}$ & $\begin{array}{l}\text { Haemorrhage }- \text { Ari (21) } \\
\mathrm{ICV}=0.94\end{array}$ & $\begin{array}{l}\text { Liver disorder - Mo (15) } \\
\mathrm{ICV}=0.94\end{array}$ \\
\hline POS - Antidote, snake bite, scorpion sting, fish stupefying & 4 & $\begin{array}{l}\text { Snake bite }-P p(18) \\
\text { ICV }=0.90\end{array}$ & $\begin{array}{l}\text { Scorpion sting }- \text { Acv (18) } \\
\mathrm{ICV}=0.90\end{array}$ & $\begin{array}{l}\text { Antidote }- \text { Asp (15) } \\
\mathrm{ICV}=0.90\end{array}$ \\
\hline
\end{tabular}

CVC - Cardiovascular, DER - Dermatological, DIG - Digestive, GUS - Genito-urinal, INF - Infections, INJ - Injuries, MSK - Musculo-skeletal, NVS - Nervous, OPTH - Ophthalmic, OTH - Others, POS - Poisonous, PRG - Pregnancy, RES - Respiratory

$A a=$ Angelica archangelica $(\mathrm{KU}$ 07210), Ac $=$ Acorus calamus (KU 07234), Ach $=$ Anthocephalus chinensis (KU 07220),Acv $=$ Adiantum capillis-veneris $(\mathrm{KU} 07224), A p=A b r u s$ precatorius $(\mathrm{KU}$ 07209), Ar $=$ Asparagus racemosus (KU 07221), Ari = Astilbe rivularis (KU 07231), Asp = Aconitum species (KU 07233), Ba = Berberis asiatica (KU 07246), BC = Bergenia ciliata (KU 07252), Bv = Bauhinea vahlii (KU 07240), Ca = Curcuma aromatica, Cas = Centella asiatica (KU 07276), Cn = Coriaria nepalensis (KU 07247), $\mathrm{Cs}=$ Cordyceps sinensis (KU 07241), Co = Curculigo orchioides (BKU 020), Cop = Colebrookea oppositifolia (KU 07232), Cr = Cuscuta reflexa (BKU 053), $\mathrm{Ct}=$ Cinnamomum tamala (BBU 095), Dh = Dactylorhiza hatagirea (KU 07271), Ep = Eclipta prostrata (BKU 055), Eph = Entada phaseoloides (KU 07236), Fn = Fragaria nubicola (KU 07242), Jc = Jatropha curcas (BBU 056), $\mathrm{Jr}=$ Juglans regia (KU 07272), Mc = Morchella conica (KU 07243), Mh = Melothria heterophylla (KU 07255), Mk = Murraya koenigii (BBU 091), Mo = Moringa oleifera (KU 07237), Mp = Mallotus philippensis (BKU 092), $\mathrm{Ms}=$ Mentha spicata (BKU 058), $\mathrm{Ng}=$ Nardostachys grandiflora (DBU 060), Ns = Neopicrorhiza scrophulariflora (DKU 090)

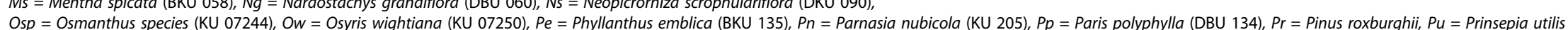

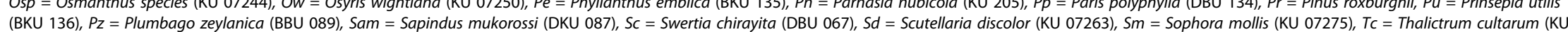
07284), Ud = Urtica dioica (KU 07290), V $=$ Valeriana jatamansii (KU 07279), Za = Zanthoxylum armatum (KU 07291). 
attributed to the expansion of commercial demand for medicinal plants and higher market prices.

All family members of local farmers and traditional healers were generalist collectors, but their children and elders were sometimes used in collection of forest products from nearby and accessible areas. Most household heads that have been collecting plants/products since infancy use their children for support. We found that about $20 \%$ of the collectors were children, but their involvement was limited, particularly to private farmlands, lower elevations, and accessible areas. Children were guided to collect produce and products of Prinsepia utilis, Rhus parviflora, Murraya koenigii, Zanthoxylum armatum, Berberis asiatica, Centella asiatica, etc. In particular, children were trained to collect the leaves and fruits of useful species. Children and elders were most seldom used in the collection of high-value medicinal plants and products found at higher elevations, such as Cordyceps sinensis, Morchella species, etc., thanks to the climatic and physiographic adversity associated with their collection. The species valued for their rhizomes and bark were commonly uprooted or debarked by elderly groups. There was a range of collection of medicinal plants in each household $(\mathrm{N}=252)$ from $0.6 \mathrm{Kg}$ to $720 \mathrm{Kg}$ of fresh products.

Besides forests, private farmlands were also important in the supply of medicinal plant products. About $32 \%$ of collections of medicinal plant products were from private farmlands. In some private farmlands, plants such as Sapindus mukorossi, Z. armatum, Phyllanthus emblica, and Swertia chirayita, which fetch good market prices, were intentionally cultivated. Other medicinal plants that occur naturally in farmlands were Pyrus pashia, Ficus hispida, Acmella calva, Amaranthus viridus, Choerospondias axillaris, etc. These plants were under-utilized [39].

\section{Marketing of medicinal plants}

As shown by Olsen and Larsen [20], the livelihoods of people of western Nepal heavily depend on the collection and trade of medicinal plants. Within the three districts that were studied, a total of 42 species or products were found to be collected and traded for both subsistence and commercial purposes (Table 2). The data ranged from 40 for Baitadi to 36 for Darchula and 28 for Dadeldhura. Twenty two items were common to all three districts. Earlier reports indicated that the number of traded species in and around the study area was between 26 and 42 [31,32]. The numbers for Nepal as a whole are between 125 and 178 [40-42].

An average of 20,000 tons of raw materials, worth between \$8.6-\$27 million (\$US) annually, are traded and/or exported from Nepal [43,44]. However, official records only record a much lower volume $(25 \%-50 \%)$. Of the five political divisions in Nepal (East, Central, West, Mid-west and Far-west), the Far-west contributes about $20 \%$ of the total volume of medicinal and aromatic plants traded from country. The three study districts (Baitadi, Dadeldhura, and Darchula) alone contribute $17.4 \%$ of the country's total traded volume; this accounts for $78 \%$ of the Far-west trade [45]. Among the three study districts, Baitadi is rich in medicinal and aromatic plants and alone contributes about $10 \%$ of the national traded volume. S. mukorossi and $Z$. armatum were the species traded in the largest volume in the country, and both the species are indigenous to western Nepal.

Income from medicinal plants comprised a significant portion (20\%) of the annual cash income of local people in study area. It was computed against different wealth indices, and it represented the highest percentage of income for the Janajati and Dalits groups, which was consistent with their gradual increase in numbers per annum. The annual increase in income from medicinal plant collection and cultivation was shown to go from N.Rs. 4,223 in 2006 to N.Rs. 5,802 in 2007. A similar increase was also noted by Acharya and Tamrakar [30] from N.Rs. 1,326 in 2005 to N.Rs. 9,290 in 2009. In other parts of Nepal, the contribution of medicinal plants to annual cash income was about 15\% [43,44], and in some cases was as high as $30 \%-50 \%$ [18].

\section{Traditional use}

A total of 49 species possessed an ICV more than 0.85, and all these species possessed matching information from at least 20 respondents (mentions). Use of plants for treatment of 60 ailments in 13 disease categories was recorded following Phillips and Gentry [46] (Table 1). Digestive system disorders were frequent and their treatment with locally available medicinal plants was the most consistent with the findings of Kumar et al. [47]. Informants described the usefulness of 44 species for digestive disorders (Table 1). There was a broad consensus for the use of $C$. sinensis as an aphrodisiac and B. asiatica for eye problems. Furthermore, Bergenia ciliata was often mentioned for the treatment of the disintegration of calculi, S. mukorossi for dandruff, and $Z$. armatum for toothache; these treatments share the highest consensus value. This high ICV indicates that use of these species is widely known in study area, and most of the respondents concurred regarding the particular usage. This paper takes the position that informant consensus is a reliable method of selecting medicinal plant for pharmacological evaluation [48].

Traditional uses of C. sinensis as a tonic, aphrodisiac, immuno-stimulant, and for retention of memory coincided with previous pharmacological findings. The adenosine found in $C$. sinensis has widespread effects on circulation of blood, cerebral and coronary effects [49,50], prevention of cardiac arrhythmias [51], inhibition of neurotransmitter release [52], potentiating immune system [53], and antitumor activity [54]. The Ayurvedic and folk usage of $B$. ciliata as an antidiarrheal and antidysenteric $[55,56]$ also 
Table 2 List of species/products traded from districts

\begin{tabular}{|c|c|c|c|c|c|c|}
\hline SN & Trade name & Botanical name & Baitadi & Dadeldhura & Darchula & Common in all districts \\
\hline 1. & Amala & Phyllanthus emblica & + & + & + & + \\
\hline 2. & Bhorla Bokra & Bauhinia vahlii & + & + & + & + \\
\hline 3. & Bhyakur & Dioscorea species & + & + & + & + \\
\hline 4. & Bishjara & Aconitum species & + & + & + & + \\
\hline 5. & Chiraito & Swertia chirayita & + & + & + & + \\
\hline 6. & Chutro & Berberia asiatica & + & + & + & + \\
\hline 7. & Dalchini & Cinnamomum tamala & + & + & + & + \\
\hline 8. & Daruhaldi & Mahonia nepalensis & + & + & + & + \\
\hline 9. & Jhyau & Lichen species & + & + & + & + \\
\hline 10. & Kachur & Curcuma aromatica & + & + & + & + \\
\hline 11. & Kauloko bokra & Persea species & + & + & + & + \\
\hline 12. & Miscellaneous & & + & + & + & + \\
\hline 13. & Pakhanbed & Bergenia ciliata & + & + & + & + \\
\hline 14. & Pawan Bokra & & + & + & + & + \\
\hline 15. & Rittha & Sapindus mukorossi & + & + & + & + \\
\hline 16. & Tejpat & Cinnamomum tamala & + & + & + & + \\
\hline 17. & Timur & Zanthoxylum armatum & + & + & + & + \\
\hline 18. & Chatiwan & Alstonia scholaris & + & + & + & + \\
\hline 19. & Chyau & Mushroom & + & + & + & + \\
\hline 20. & Kakarsingi & Pistachia chinensis & + & + & + & + \\
\hline 21. & Satuwa & Paris polyphylla & + & + & + & + \\
\hline 22. & Kurilo & Asparagus racemosus & + & + & + & + \\
\hline 23. & Barro & Terminalia belerica & + & + & & \\
\hline 24. & Bojho & Acorus calamus & + & + & & \\
\hline 25. & Jiwanti & Ephemerantha macarei & + & + & & \\
\hline 26. & Lokta & Daphne bholua & + & + & & \\
\hline 27. & Somlata & Ephedra gerardiana & + & + & & \\
\hline 28. & Sugandhwal & Valeriana wallichii & + & + & & \\
\hline 29. & Bajradanti & Potentilla fruticosa & + & & + & \\
\hline 30. & Bhojpatra & Betula utilis & + & & + & \\
\hline 31. & Bhutkesh & Jurenia dolomiea & + & & + & \\
\hline 32. & Dhupipat & Juniperus species & + & & + & \\
\hline 33. & Guchhi & Morchella conica & + & & + & \\
\hline 34. & Katush & Castanopsis species & + & & + & \\
\hline 35. & Kutjara & & + & & + & \\
\hline 36. & Kutki & Neopicrorhiza scrohpularoflora & + & & + & \\
\hline 37. & Nirmansi & Delphinium denundatum & + & & + & \\
\hline 38. & Setak chini & Moringa oleifera & + & & + & \\
\hline 39. & Siltimur & Litsea cubeba & + & & + & \\
\hline 40. & Thingresalla & Abies spetabilis & + & & + & \\
\hline 41. & Aank bhuwa & Calotropis gigantea & & & + & \\
\hline 42. & Yarsagumba & Cordyceps sinensis & & & + & \\
\hline
\end{tabular}


corroborated earlier reports [6,9]. The fruits of $Z$. armatum were commonly used to treat toothache in folklore and Ayurvedic medicines, and their anti-inflammatory [57] and antibacterial [58] actions have been substantiated. The use of root bark extract of $B$. asiatica to treat conjunctivitis was common [55,59], and its effectiveness as an antimicrobial [60], anesthetic, antihypertensive, and pigment inducer [61] has been clinically verified. Sapindus fruits were commonly applied to fight dandruff. Sapindus' emetic and expectorant properties have previously been mentioned in the Ayurveda [55] and antichlamydiac property in pharmacology [62]. The folk use of Cuscuta reflexa for jaundice was supported by pharmacological studies, showing it possesses strong antibacterial actions [63].

\section{Plant parts used and mode of preparation}

Plant parts used for ethnomedicinal preparations were bark, fruit, flower, inflorescence, leaf, root, rhizome, stem, seed, wood, and the whole plant. The most frequently utilized plant parts were roots and rhizomes of 38 species, followed by fruits of 26 species, leaves of 22 species, etc. (Figure 2). Underground parts were frequently used, and this was attributed to presence of bioactive compounds [64]. Preparation methods for therapies included decoction, drying, and extraction. Plant infusion/smoke, juice, latex, oil, paste, powder, raw/fresh and resin were also applied (Figure 3). Plant juice (39.13\%) was most commonly used, followed by decoction (13.04\%), paste (10.86\%), etc. The most popular forms of medicinal preparations in western Nepal are juice, decoction, paste, infusion, and powder [65] (Figure 4).

\section{Traditional therapies}

Home herbal remedies, folklore medicine, and the Baidhya healing system are commonly found in the study area. The persistence of these traditional therapies is due to the high cost of modern medicine and the absence of trained physicians. It is estimated that there is one physician per 30,000-100,000 people in Nepal [66], whereas there is at least one healer for every 100 people [67]. Data show that there is at least one health worker for every 670 people in Baitadi, 663 in Dadeldhura, and 509 in Darchula district [68]. Interest in traditional therapies has gradually increased over the recent years $[6,39,69]$. All these reasons foster the persistence of traditional therapies in the study area. This is reinforced by the preference of local people for traditional medicine, thanks to their belief in its effectiveness and to a lack of alternative choices [70,71]. All these therapies were culturally intertwined. The number of plants used as ethnomedicines was also higher in the mountains of the Nepalese Himalayas [5]. However, traditional knowledge and the plants for folk therapies are gradually being endangered due to changing lifestyles, perceptions, social transformations, and acculturation.

\section{Management}

The many uses of medicinal plants for trade and subsistence needs have led to conflict and overexploitation. An account of the multiple uses of medicinal plants that in turn threaten those very plants as a result of overharvesting has been noted in India [72]. Deliberate forest fires and premature harvests endanger existing populations of medicinal plants. The quantity and quality of medicinal plants within the study area have been degraded by market-led premature exploitation and climate change. The changes to plant phenology, range, and growth behavior as a result of climate change also jeopardize species survival and quality products $[73,74]$. Price differentials between wild and cultivated products, which reflect the demand for wild crafted products, encourage unsustainable collection.

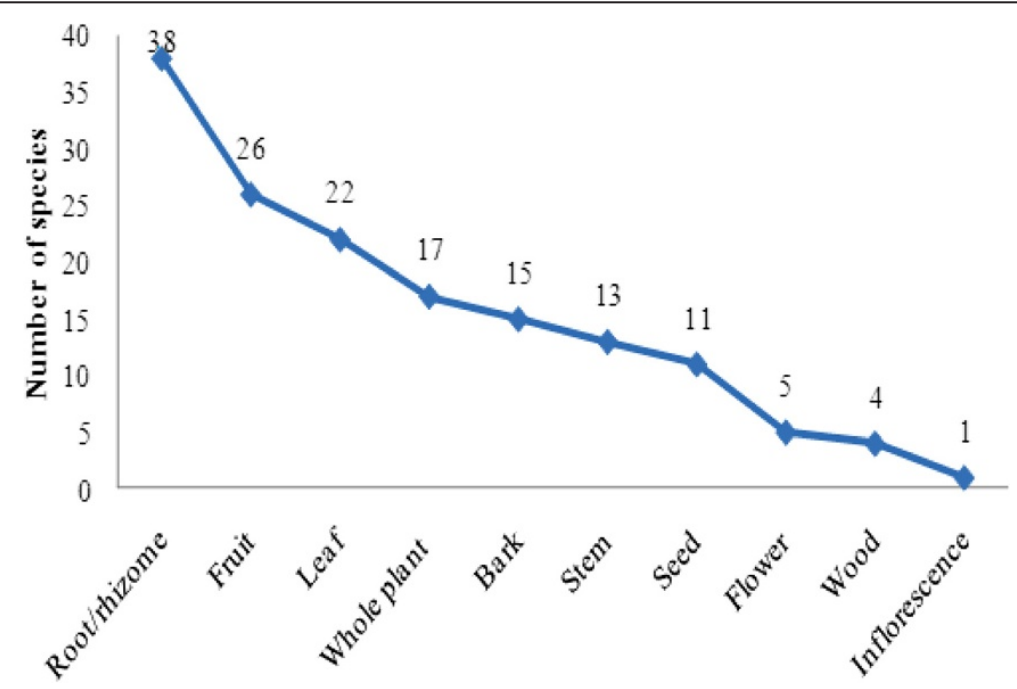

Figure 2 Plants parts used for curving. 


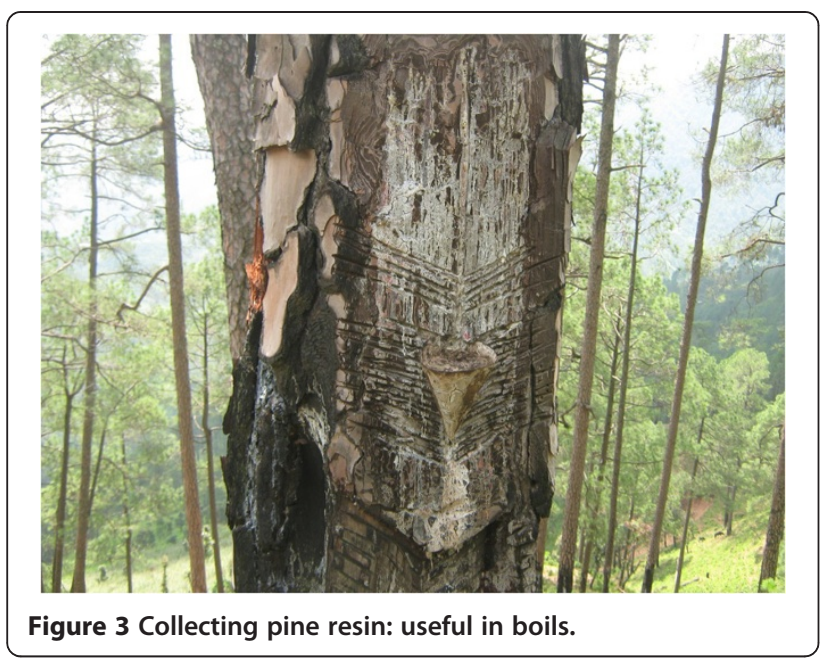

Over-harvesting was also threat to many indigenous medicinal plant species, such as $Z$. armatum, $N$. grandiflora, A. rivularis etc. The collection of medicinal plants in a sustainable manner is imperative for development and conservation [75].

In order to conserve indigenous and high value medicinal plants, the government of Nepal outlawed the collection and trade of 17 important medicinal plant species [76] and has urged citizens to cultivate 30 highly valued species [77]. These initiatives have proven inadequate [78]. Because of the firm relationship between medicinal plants and rural livelihood (Figure 5), it is unlikely that a legal ban can be enforced [79] due to complex management systems [80], invigorating cultivation, and sustainable management. Community-based organizations have also attempted to conserve medicinal plant resources and revitalize indigenous resource management systems. The Himalayan Amchi Association (HAA), an institution aimed at safeguarding

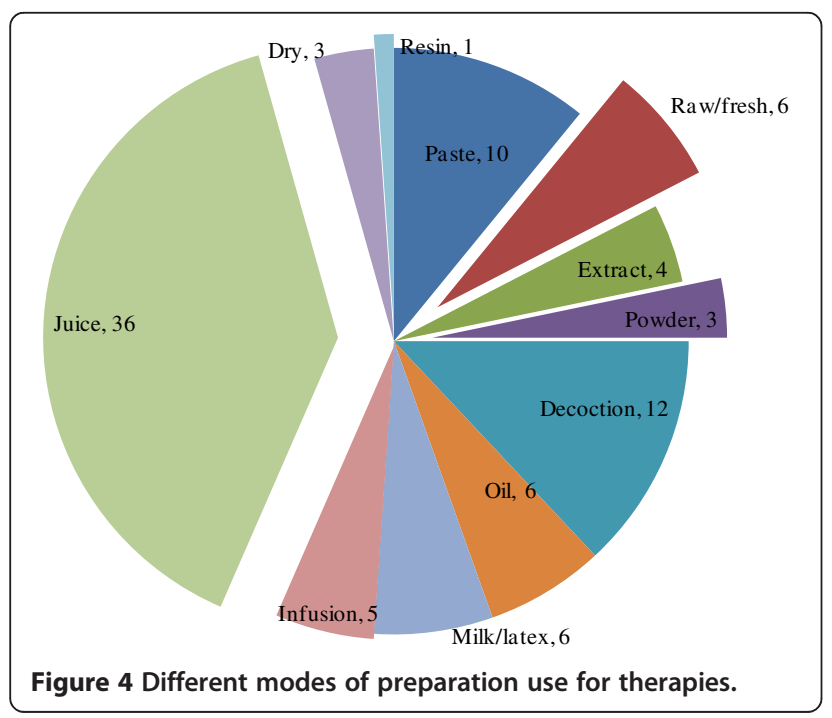

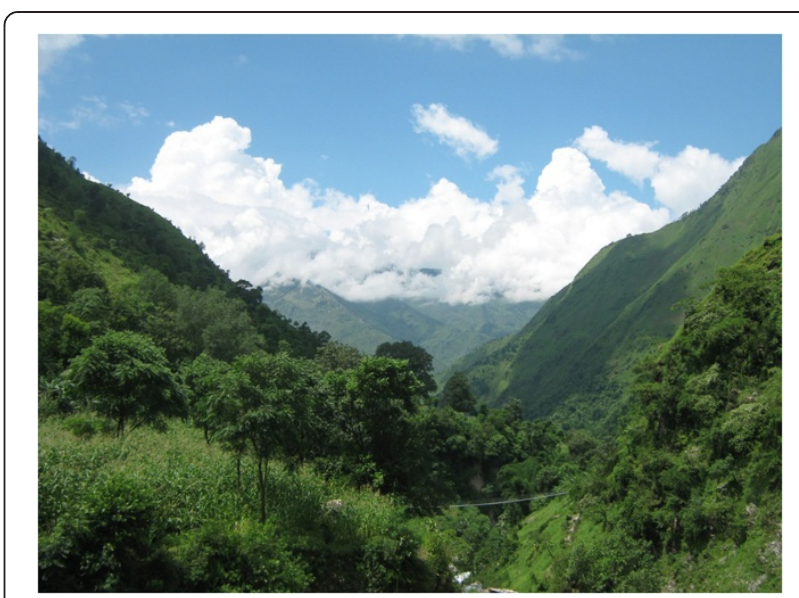

Figure 5 Ecological landscape favorable for medicinal plant growth.

traditional health care knowledge [81], is devoted to protect medicinal plants and strengthen the knowledge of Amchi healers [82,83]. The Amchi health care system, influenced from Tibetan Chinese medicine, is active in the high hills and mountainous districts of Nepal [7]. The Baidhya healing system, prevalent in the mid-hills of western Nepal [14], is influenced by the Ayurveda. Baidhya medicinal practitioners (particularly of western Nepal mid hills [71] and adjoining areas of India [84]) were common among privileged groups and pursued remedies to cure diseases and aliments by using nearby medicinal plants. Their knowledge base for therapies stems from custom, livelihood strategies, and available resources. Because of their prolonged existence and use, these systems and therapies are inseparable from local culture. Strengthening wise use and conservation of resources and knowledge of healing systems, which are culturally inherited and valued as well as scientifically important, may complement pharmacology [19] and the livelihood of communities inhabiting remote and high-altitude areas of the western Himalaya [85].

\section{Conclusions}

Medicinal plants play a substantial role in the life support systems of local communities of Far-west Nepal. With increasing acceptance and use of medicinal plants in traditional therapies, and with increasing commercial demands over the years, the consumption and collection of medicinal plants is accelerating and thus endangering the extant populations. Over-harvesting threatens many indigenous medicinal plant species, such as $Z$. armatum, $N$. grandiflora, $A$. rivularis etc. Collection and consumption of medicinal plants in a sustainable manner is an integrated process with potential for development and conservation. Indigenous knowledge of medicinal plant use for traditional therapies and sustainable management in Nepal is empirically based, 
culturally inherited and intertwined, and important to pharmacology and local livelihoods. However, it is currently being eroded due to changing lifestyles, perceptions, social transformations, and acculturation. The conservation and sound management of indigenous knowledge of medicinal plants is thus strongly urged.

\section{Competing interests}

The authors declare that they have no competing interests.

\section{Authors' contributions}

RMK, RPA, and LM carried out field studies. RMK and RPA analyzed data and prepared manuscript. RWB edited the manuscript, further analyzed the data, and finalized the article. All authors approved the final version of this manuscript.

\section{Acknowledgments}

The authors wish to thank the Canadian Center for International Studies and Cooperation (CECI) and the International Center for Integrated Mountain Development (ICIMOD), both located in Kathmandu, for providing facilities for field studies and data analysis. RMK is grateful to the William L. Brown Center at the Missouri Botanical Garden for providing financial support to carry out field visits, conduct a literature review, and do the data analysis. The authors are also thankful to two anonymous reviewers and B Ponmann to review this manuscript for their helpful comments.

\section{Author details}

${ }^{1}$ Center for Biological Conservation, Kathmandu, Nepal. ${ }^{2}$ Central Department of Sociology/Anthropology, Tribhuvan University, Kathmandu, Nepal. ${ }^{3}$ Practical Solution Consultancy, Kathmandu, Nepal. ${ }^{4}$ William L. Brown Center, Missouri Botanical Garden, P.O. Box 299, St. Louis, MO 63166-0299, USA.

Received: 18 November 2012 Accepted: 7 April 2013

Published: 12 April 2013

\section{References}

1. Bhattarai KR, Maren IE, Chaudhary RP: Medicinal plant knowledge of the Panchase region in the middle hills of the Nepalese Himalaya. Banko Janakari 2011, 21(2):31-39.

2. Kunwar RM, Shrestha K, Dhungana SK, Shrestha PR, Shrestha KK: Floral Biodiversity of Nepal: an update. Journal of Natural History Museum 2010, 25:295-311

3. Uprety Y, Asselin H, Boon EK, Yadav S, Shrestha KK: Indigenous use and bio-efficacy of medicinal plants in the Rasuwa District, Central Nepal. J Ethnobiol Ethnomed 2010, 6:3. www.ethnobiomed.com/content/6/1/3.

4. Kunwar RM, Bussmann RW: Ethnobotany in the Nepal Himalaya. J Ethnobiol Ethnomed 2008, 4:24. www.ethnobiomed.com/content/4/1/24.

5. Manandhar NP: Plants and People of Nepal. Oregon, USA: Timber press Inc. Portland; 2002:599

6. Kunwar RM, Nepal BK, Kshhetri HB, Rai SK, Bussmann RW: Ethnomedicine in the Himalaya: a case study from Dolpa, Humla, Jumla and Mustang district of Nepal. J Ethnobiol Ethnomed 2006, 2:27. www.ethnobiomed.com/ content/2/1/27.

7. Rokaya MB, Munzbergova Z, Shrestha MR, Timsina B: Ethnobotanical study of medicinal plants from the Humla district of western Nepal. J Ethnopharmacol 2010, 130:485-504.

8. Baral SR, Kurmi PP: Compendium of medicinal plants in Nepal. Chabahil, Kathmandu, Nepal: Rachana Sharma publishers; 2006:534.

9. Shengji JP: Ethnoecological approaches of traditional medicine studies: some experiences from Asia. Pharmacoceutical Biology 2001, 39:74-79.

10. WHO: WHO traditional medicine strategy 2002-2005. Geneva: World Health Organization; 2002.

11. Tiwari S, Robinson J, Amatya G: Community based approaches to conservation and management of MAPs for sustainable livelihood in Doti district, West Nepal. In Proceeding of local experience-based national strategy for organic production and management of MAPS/NTFPs in Nepal. Edited by Bhattarai NK, Karki M. Kathmandu: IDRC, MAPPA and Government of Nepal; 2004:97-127.

12. WWF: Medicinal plant trade: wildlife trade. World Wildlife Foundation; 2000. http://wwf.panda.org/who_we_are/wwf_offices/india/?uProjectID=9Z0718.
13. Karki M: The organic production of medicinal and aromatic plants: a strategy for improved value-addition and marketing of products from the Himalayas. In Proceeding of wise practices and experimental learning in conservation and management of Himalayan medicinal plants. Edited by Thomas YA, Karki M, Gurung K, Parajuli D. Kathmandu, Nepal: Ministry of Forests and Soil Conservation; 2005:56-69.

14. Singh MP, Malla SB, Rajbhandary SB, Manandhar A: Medicinal plants of Nepal - retrospects and prospects. Economic Botany 1979, 33:185-198.

15. Olsen CS, Larsen HO: Alpine medicinal plant trade and Himalayan mountain livelihood strategies. The Geographical Journal 2003, 169:243-254.

16. Sharma PP, Mujundar AM: Traditional knowledge on plants from Toranmal Plateau of Maharastra, India. Indian Journal of Traditional Knowledge 2003, 2:292-296.

17. Bussmann RW: Ethnobotany and biodiversity conservation. In Modern trends in applied terrestrial ecology. Edited by Ambasht RS, Ambasht NK. Kluwer Publishers: New York; 2002:345-362.

18. Bhattarai NK: Biodiversity-people interface in Nepal, Medicinal Plants for Forest Conservation and Health Care. FAO and UN Rome, Italy: NWFP Bulletin; 1997:11.

19. Patwardhan B, Warude D, Pushpangadan P, Bhatt N: Ayurveda and traditional Chinese medicine: a comparative overview. eCAM 2005, 2(4):465-473.

20. Kunwar RM, Uprety Y, Burlakoti C, Chowdhary CL, Bussmann RW: Indigenous use and ethnopharmacology of medicinal plants in far-west Nepal. Journal of Ethnobotany Research \& Applications 2009, 7:5-28.

21. Lambert J, Srivastava J, Vietmeyer N: Medicinal Plants: Rescuing a Global Heritage. USA: The World Bank; 1997.

22. Ramakrishnan PS, Chandrashekara UM, Elouard C, Guilmoto CJ, Maikhuri RK, Rao KS, Sankar S, Saxena KG: Mountain biodiversity, land use dynamics, and traditional ecological knowledge. New Delhi, India: Oxford and IBH Publishing Co; 2000.

23. Ghimire SK, McKey D, Thomas YA: Himalayan medicinal plant diversity in an ecologically complex high altitude anthropogenic landscape, Dolpo, Nepal. Environmental Conservation 2006, 33:128-140.

24. Bennet L: Gender, caste and ethnic exclusion in Nepal: following the policy process from analysis to action. Arusha, Tanzania: Paper presented at the conference New Frontiers of Social policy: development in a globalizing world; 2005. http://siteresources.worldbank.org/ INTRANETSOCIALDEVELOPMENT/Resources/Bennett.rev.pdf.

25. Martin GJ: Ethnobotany: A methods manual. London: Earthscan Publications; 2004.

26. Dahal DR: Social composition of the population: case/ethnicity and religion in Nepal. In Population monograph of Nepal. 1st edition. Central Bureau of Statistics, Government of Nepal. http://cbs.gov.np/wp-content/ uploads/2012/Population/Monograph.

27. Polunin O, Stainton A: Flowers of the Himalaya. New Delhi-India: Oxford University Press; 1984:580.

28. Stainton A: Flowers of the Himalaya, a supplement. New Delhi-India: Oxford University Press; 1998. 86.

29. Kunwar RM: Ecology and economy of medicinal, aromatic and dye plants for sustainable livelihood, west Nepal: an assessment. Kathmandu, Nepal: Canadian Center for International Studies and Cooperation; 2007:32.

30. Acharya RP, Tamrakar R: Livelihood and poverty impacts of MAPPA project in west Nepal. Kathmandu, Nepal: International Center for Integrated Mountain Development (ICIMOD); 2009:68.

31. ANSAB: Market Assessment of Non Timber Forest Products in Darchula and Baitadi Districts, Far-west Nepal. Kathmandu: Asia Network for Sustainable Agriculture and Bioresources; 2003.

32. CMAPSL: Conservation of medicinal and aromatic plants for sustainable livelihood project. Report. Kathmandu, Nepal: Canadian Center for International Studies and Cooperation; 2005.

33. Trotter RT, Logan MH: Informant consensus: a new approach for identifying potentially effective medicinal plants. In Plants in indigenous medicine and diet. Edited by Ektin NL. Bedford, US: Redgrave Publication Co; 1986:91-112

34. Kunwar RM, Duwadee NPS: Ethnobotanical notes on flora of Khaptad National Park, far-western Nepal. Himalayan Journal of Sciences 2003, 1:25-30

35. Narendran K, Murthy IK, Suresh HS, Dattaraja HS, Rabindranath NH, Sukumar R: NTFP extraction, utilization and valuation; a case study from the Nilgiri Biosphere Reserve, India. Economic Botany 2001, 55:528-538.

36. Ives JD: The theory of Himalayan degradation: its validity and application challenged. Mountain Research and Development 1987, 7:189-199.

37. Ostrom E: Governing and managing forests and other common property resources in a period of climate change. 2010. http://www.icimod.org/?q=719.

38. Gaire D: Effectiveness and representation of poor, women and Dalitss in executive committee: process and achievement; a study from the buffer zone of 
Bardia National Park, Nepal. MSc thesis. Kathmandu, Nepal: Institute of Forestry, Tribhuvan University; 2007.

39. Kunwar RM, Mahat L, Sharma LN, Shrestha KP, Kominee H, Bussmann RW: Underutilized plant species in far west Nepal. Journal of Mountain Science 2012, 9:589-600.

40. Kunwar RM, Shrestha KP, Bussmann RW: Traditional herbal medicine in Far-west Nepal: a pharmacological appraisal. J Ethnobiol Ethnomed 2010, 6:35. www.ethnobiomed.com/content/6/1/35

41. Bhattarai KR, Ghimire M: Commercially important medicinal and aromatic plants of Nepal and their distribution pattern and conservation measure along the elevation gradient of the Himalayas. Banko Janakari 2006, 16(1):3-13.

42. Srivastava D: Resources of Nepalese medicinal and aromatic plants: status and development. Plant Resources 2009, 31:127-131.

43. Edward DM: Non-Timber Forest Products from Nepal: Aspect of the trade in medicinal and aromatic Plants. Kathmandu, Nepal: Ministry of Forests and Soil Conservation; 1996:1-96. FORESC monograph.

44. Subedi BP: Utilization of Non-Timber Forest Products: Issue and strategies for environmental conservation and economic development. Kathmandu, Nepal: Asia Network for Sustainable Agriculture and Bio-resources; 1997.

45. GoN: Hamro Ban (Our Forests). Babarmahal, Kathmandu, Nepal: Government of Nepal. Ministry of Forests and Soil Conservation; 2005.

46. Phillips O, Gentry AH: The useful plants of Tambopata, Peru: Il. Additional hypothesis testing in quantitative ethnobotany. Economic Botany 1993, 47:33-43.

47. Kumar M, Sheikh MA, Bussmann RW: Ethnomedicinal and ecological status of plants in Garhwal Himalaya, India. J Ethnobiol Ethnomed 2011, 7:32. www.ethnobiomed.com/content/7/1/32.

48. Etuk EU, Mohammed BJ: Informant consensus selection method: A reliability assessment on medicinal plants used in north western Nigeria for the treatment of diabetes mellitus. African Journal of Pharmacy and Pharmacology 2009, 3(10):496-500. http://www.academicjournals.org/ajpp/ abstracts/abstracts/abstracts2009/October/Etuk\%20amd\%20Mohammed.htm.

49. Berne RM: The role of adenosine in the regulation of coronary blood flow. Cancer Research 1980, 47:807-813.

50. Toda S, Kumura M, Ohnishi M: Effects of phenolcarboxylic acids on superoxide anion and lipid peroxidation induced by superoxide anion. Planta Medica 1991, 57:8-10.

51. Pelleg A, Porter RS: The pharmacology of adenosine. Pharmacotherapy 1990, 10:157-174.

52. Ribeiro JA: Purinergic inhibition of neurotransmitter release in the central nervous system. Pharmacol Toxicol 1995, 77:299-305.

53. Xu RH, Peng XE, Chen GZ, Chen GL: Effects of Cordyceps sinensis on natural killer activity and colony formation of B16 melanoma. Chin Med J 1992, 105:97-101.

54. Chen YJ, Shiao MS, Lee SS, Wang SY: Effect of Cordyceps sinensis on the proliferation and differentiation of human leukemic U937 cells. Life Sciences 1997, 60:2349-2359.

55. Bajracharya MB: Ayurvedic medicinal plant and general treatments. Kathmandu, Nepal: Jore Ganesh Press Pvt. Ltd; 1979:230.

56. Dey AC: Indian medicinal plants used in Ayurvedic preparation. Dehra Dun India: Bishen Singh Mahendra Pal Singh; 1998.

57. Kumar S, Ziereis K, Wiegrebe W, Muller K: Medicinal plants from Nepal: evaluation as inhibitors of leukotriene biosynthesis. J Ethnopharmacol 2000, 70:191-195.

58. Taylor RSL, Shahi S, Chaudhary RP: Ethnobotanical research in the proposed Tinjure-Milke-Jaljale Rhododendron conservation area, Nepal. In Vegetation and society: Their interaction in the Himalayas. Edited by Chaudhary RP, Subedi BP, Vetaas OR, Aase TH. Norway: Tribhuvan University, Nepal and University of Bergen; 2002:26-37.

59. Das B, Gupta K: Materia medica of Ayurveda based on Mandanapala's Nighantu. New Delhi, India: B. Jain Publishers; 1994:780.

60. Iwasa K, Namba H, Lee DU, Kang SI: Structure-activity relationships of protoberberines having antimicrobial activity. Planta Medica 1998, 64:748-751.

61. Sabir M, Bhide MK: Study of some pharmacological activities of berberine. Indian Journal of Physiology and Pharmacy 1971, 15:111-132.

62. Garg A: Effect of Calotropis procera (Ait.) R. Br. flower extract on testicular function of the Indian desert male gerbil Meriones hurrianae Jerdon: a biochemical and histological study. Indian Journal of Experimental Biology 1979, 17:859-862.

63. Tiwari BR, Raut B: Screening of selected medicinal plants of Pokhara valley for their antimicrobial activities. Journal of Natural History Museum 2009, 24:16-20.
64. Moore PD: Trials in Bad Taste. Nature 1994, 370:410-411.

65. Burlakoti C, Kunwar RM: Folk herbal medicines of Mahakali watershed area, Farwest Nepal. In Medicinal plants in Nepal: An anthology of contemporary research. Edited by Jha PK, Karmacharya SB, Chettri MK, Thapa CB, Shrestha BB. Kathmandu, Nepal: Ecological Society; 2008:187-193.

66. Gillam S: The traditional healer as village health worker. Journal of Institute of Medicine 1989, 11:67-76.

67. WRI: World Resources - 2005. The wealth of the poor: managing ecosystems to fight poverty. World Resource Institute, USA; 2005. http://www.wri.org/publication/ world-resources-2005-wealth-poor-managing-ecosystems-fight-poverty, http:// pdf.wri.org/wrr05_dt_all.pdf.

68. Anonymous: District profile. Kathmandu, Nepal: Mega Research Center and Publication; 2010.

69. Craker LE, Gardner ZE: Medicinal plants and tomorrow's pharmacy. In Medicinal and aromatic plants. Proc. Frontis Workshop on Medicinal and Aromatic Plants. Edited by Bogers J, Craker LE, Lange D. Wageningen: Nucleus for Strategic Expertise Wageningen University and Research Centre; 2006:29-41. Wageningen, The Netherlands, 17-20, April 2005.

70. Bhattarai NK: Traditional herbal medicines used to treat wounds and injuries in Nepal. Tropical Doctor 1997, 27(1):43-47.

71. Bhattarai NK: Medical ethnobotany in the Karnali Zone, Nepal. Economic Botany 1992, 45(3):257-261

72. Appasamy PP: Role of NTFPs in subsistence economy: The case of joint forestry project in India. Economic Botany 1993, 47(3):258-267.

73. Sala O, et al: Global biodiversity scenarios for the year 2100. Science 2000, 287:1770-1774.

74. Kunwar RM, Katuwal Y, Shrestha RD, Karki J, Shrestha K, Bussmann RW: Climate Change, Medicinal Plants and Ethnobotany: Observations and Review. In Proceeding of first national youth conference on environment. Kathmandu, Nepal: Himalayan Alliance for Climate Change; 2010:180-189. www.himcca.org.

75. Hall P, Bawa KS: Methods to assess the impact of extraction of non-timber forest products on plant populations. Economic Botany 1993, 47:234-247.

76. GoN: Protected Plants of Nepal. Kathmandu, Nepal: Ministry of Forests and Soil Conservation, Forest regulation 1995 and its amendments; 2001

77. HNCC: Prioritized medicinal plants for economic growth in Nepal. Kathmandu, Nepal: Herbs and NTFPs Co-ordination Committee, Department of Plant Resources; 2006:125.

78. Singh AG, Kumar A, Tewari DD: An ethnobotanical survey of medicinal plants used in Terai forest of western Nepal. J Ethnobiol Ethnomed 2012, 8:19. http://www.ethnobiomed.com/content/8/1/19.

79. Shrestha BB, Jha PK: Habitat range of two alpine medicinal plants in a transHimalayan dry valley, central Nepal. Journal of Mountain Science 2009, 6:66-77.

80. Messerschmidt DA, Rayamajhi S: Upper slopes forest management in Kavre and Sindhupalchok districts, Nepal: a study on forest resource conditions and the potential for people's participation. Nepal: Nepal Australia Community Forestry Project; 1996.

81. Craig S, Bista G: Himalayan healers in transition: Professionalization, identity and conservation among practitioners of gso br rig pa in Nepal. In Proceeding of wise practices and experimental learning in conservation and management of Himalayan medicinal plants. Edited by Thomas YA, Karki M, Gurung K, Parajuli D. Kathmandu, Nepal: Ministry of Forests and Soil Conservation; 2005:411-433.

82. Kunwar RM, Parajuli RR: Good governance in natural resource management: A case study from Dolpa district, Nepal. Banko Janakari 2007, 17:17-24.

83. Lama YC, Ghimire SK, Thomas YA: Medicinal plants of Dolpo: Amchi's knowledge and conservation. WWF Nepal, Kathmandu, Nepal: People and Plants Program; 2001:150.

84. Kala CP: Current status of medicinal plants used by traditional Baidhya in Uttaranchal state of India. Journal of Ethnobotany Research \& Applications 2005, 3:267-278.

85. Uprety Y, Poudel RC, Shrestha KK, Rajbhandary S, Tiwari NN, Shrestha UB, Asselin $\mathrm{H}$ : Diversity of use and local knowledge of wild edible plant resources in Nepal. J Ethnobiol Ethnomed 2012, 8:16. http://www. ethnobiomed.com/content/8/1/16.

\section{doi:10.1186/1746-4269-9-24}

Cite this article as: Kunwar et al:: Medicinal plants, traditional medicine, markets and management in far-west Nepal. Journal of Ethnobiology and Ethnomedicine 2013 9:24. 